\title{
前立腺肥大症における肥大形態とウロダイナミックスの検討
}

\author{
原: 信病院泌沓器科 \\ 分田 裕順 ${ }^{*}$ 武井実根雄 山口 秋人
}

\section{THE CORRELATION BETWEEN URODYNAMICS AND MORPHOLOGY IN MEN WITH BENIGN PROSTATIC HYPERPLASIA}

\author{
Hironobu Wakeda*, Mineo Takei and Akito Yamaguchi \\ Department of urology, Harasanshin General Hospital \\ ${ }^{*}$ Department of urology, Miyazaki Medical College
}

(Objective) We have the impression that the degree of obstruction was stronger in the patients with a middle lobe of hyperplastic nodule than in those without such a lobe in patients with benign proststic hyperplasia. In the present study, we compared the data from a pressure-flow study (PFS) and a presence of a middle lobe.

(Materials and Methods) A transurethral resection for benign prostatic hyperplasia was performed in 2,439 patients, 798 underwent PFS. The PFS findings and the presence of a middle lobe were compared with the following parameters, namely, the bladder detrusor function, the degree of obstruction, the post-voided residual volume, the maximum flow rate, the prostate volume and the resected volume.

(Results) In the pressure-flow study, the rate of the normal bladder detrusor function was higher in the patients with a middle lobe than in those without such a lobe $(71.9$ versus $53.3 \%)$. The degree of obstruction was also stronger in the patients with a middle lobe than in those without in the patients with a normal bladder detrusor function (89.0 versus $79.4 \%$ ). Then in the patients with a middle lobe, the quantity of the post-voided residual volume was greater, however, the maximum flow rate was lower.

(Conclusion) Most patients with a middle lobe demonstrate an improved voiding ability after underwent a transurethral resection.

Key words : benign prostatic hyperplasia, morphology, pressure-flow study

要旨：(目的)前立腺肥大症に扔いて中葉肥大を認めると閉塞症状が強い印象がある. 今回我々は中葉肥 大の有無によって違いを認めるかを pressure-flow study（以下 PFS）を用いて検討した.

(対象と方法) 1986 年 1 月から 1999 年 12 月までに経尿道的前立腺切除術（以下 TUR-P）を施行した 2.439 例のうち PFS のデータがそろった 798 例を対象にした. 排尿筋収縮力, 閉塞の程度, 残尿量, 最大 尿流率，前立腺重量および切除量と中葉肥大との関係について検討を行った.

(結果) 排尿筋収縮力は中葉肥大を認める群の方が強かった $(71.9$ 対 $53.3 \%)$. 閉塞の程度を排尿筋収縮 力正常例で検討すると, 中葉肥大を認める群の方が強かった $(89.0$ 対 $79.4 \%)$ ．また中葉肥大を認める群 は認めない群より残尿量が多く, 最大尿流率が小さかった。

（結論）中葉肥大を認める群は TUR-Pにより排尿状態改善を期待できる症例が多いと考えられた. キーワード：前立腺肥大症，肥大形態，プレッシャーフロースタディー

*現 宮崎医科大学泌尿器科 
表 1 肥大結節の形態

\begin{tabular}{c|c}
\hline 肥大結節 & 症例数 \\
\hline 画葉 & 485 \\
三葉 & 236 \\
中葉 & 31 \\
その他 & 46 \\
\hline 計 & 798 \\
\hline
\end{tabular}

\section{緒言}

一般に前立腺肥大症において 6 時方向の肥大結節, いわゆる中葉肥大があると, 閉塞症状は強いと思われ ているが，実際の報告は少ない。今回我々は経尿道的 前立腺切除術（TUR-P）を施行した症例について, 中 葉肥大の有無で閉塞や，排尿筋の収縮力に違いがある かを pressure-flow study（PFS）を用いて検討したの で報告する。

\section{対象と方法}

1986 年 1 月から 1999 年 12 月までに原三信病院泌 尿器科にて TUR-Pをうけた2,439 例のうち, PFSの データが集計できた 798 例を対象とした.

uroflowmetry (以下 UFM) およびPFSには, MMS 社製 UD-2000を用いた. 検査法の概要は以下のように なる。仰卧位にて $12 \mathrm{Fr}$ ダブルルーメンカテーテル(ク リエートメディック社製）を経尿道的に膀胱内まで挿 入し, 每分 $50 \mathrm{ml}$ の速度で生理食塩水を注入する. 最大 尿意まで達したところでカテーテルを抜去し, その後 恥骨上より $17 \mathrm{G}$ ロングカテラン針 (ハッコー社製) を 膀胱内に挿入する．そのチューブより膀胱内圧を測定 しながら，立位にて排尿してもらい尿流率を測定, 最 後に膀胱穿刺チューブより残尿を測定した。

手術前の PFS のデータはSchäferのノモグラム"を 用いて解析し, 手術時の内視鏡所見と比較検討した.
図 1 肥大形態の推移

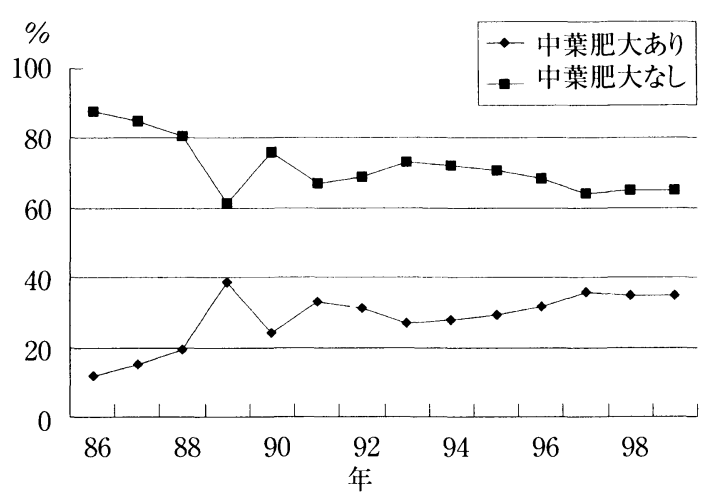

デー夕分析に際して有意差検定には unpaired t-test およびカイ 2 乗検定を用い危険率 $5 \%$ 以下を有意差あ りとし, 相関係数は Pearson's correlation coefficient を用いて検定した。

\section{1. 患者背景}

\section{結果}

肥大結節の形態を手術時の内視鏡所見にて分類する と, 両葉肥大 (右葉プラス左葉) が 485 例 $(60.8 \%)$ と 最も多かった (表 1).三葉肥大とは両葉肥大プラス中 葉肥大を認める症例であるが, 236 例 $(29.6 \%)$ であっ た. 両葉肥大を認めず中葉肥大のみを認める症例は 31 例 $(3.9 \%)$ と少なかった. なおその他 46 例 $(5.8 \%)$ に は左葉プラス中葉肥大, 右葉のみのような症例を含む. 全体で見ると中葉肥大を認める群が 278 例 $(34.8 \%)$, 認めない群が 520 例 $(65.2 \%)$ であった，手術前の国際 前立腺症状スコア（以下 IPSS）は中葉肥大を認める群 で $18.7 \pm 8.0$, 中葉肥大を認めない群で $18.5 \pm 7.7$ と差は 認めなかった $(\mathrm{p}=0.813, \mathrm{t}$ 検定 $)$.

中葉肥大を認めない群と認める群の割合を年度別に

図 2 中葉肥大と排尿筋収縮力の関係

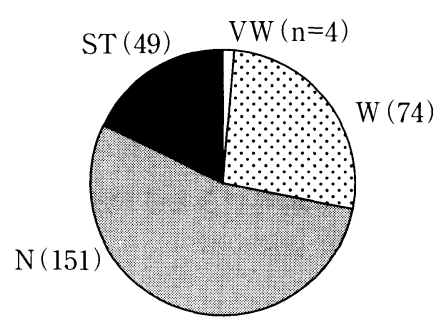

肥大あり

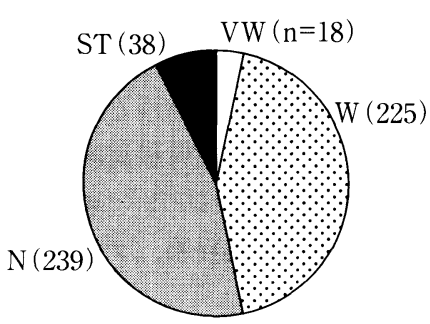

肥大な 
図 3 中葉肥大と閉塞の関係

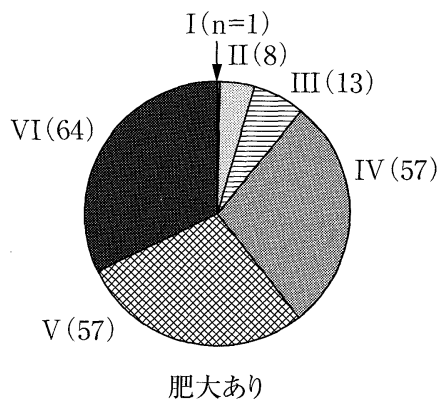

肥大あり
見ると，いずれの年度においても中葉肥大を認めない 群の割合が高い。しかし年度別の推移を見ると中葉肥 大を認める症例の割合は増加の傾向にあり $(\mathrm{r}=0.718$, $\mathrm{p}=0.0039)$ （図 1)，最近では $30 \%$ 以上を占めている.

\section{2. 年齢}

70 代が中葉肥大を認める群で $42.4 \%$, 認めない群で $43.4 \%$ と両群でピークを示した。平均年齢は全体では $70.9 \pm 7.4$ 歳, 中葉肥大を認める群で $70.3 \pm 7.6$ 歳, 認め ない群では $71.1 \pm 7.3$ 歳であった. 中葉肥大を認める群 の方が平均年齢は低い傾向にあったが，有意差は認め られなかった ( $\mathrm{p}=0.126, \mathrm{t}$ 検定 $)$.

3. 排尿筋収縮力

PFS にて Schäferのノモグラムを用いて，排尿筋収 縮力を very weak (VW 群), weak (W 群), normal (N 群)， strong (ST 群)の 4 段階に分けたところ, 中 葉肥大を認める群では $71.9 \%$ が $\mathrm{N}$ 群あるいは ST 群 と正常以上の排尿筋収縮力であった。一方中葉肥大を 認めない群では $53.3 \%$ の症例が正常以上の排尿筋収 縮力であった (図 2). 中葉肥大を認める群の方が排尿 筋収縮力は有意差をもって強かった $(\mathrm{p}<0.0001$, カイ 2 乗検定).

\section{4. 閉塞}

weak detrusor では正確な閉塞の程度を評価できな いため ${ }^{31}$ ，排尿筋収縮力が正常な症例に限って PFS を 検討した. 同様に Schäferのノモグラムを用いて, 閉塞 の程度を 0 から VI 度の 7 段階に分けて評価した. IV 度以上の高度閉塞を示す症例が中葉肥大を認める群で 89.0\%，中葉肥大を認めない群で 79.4\%であった（図 3). つまり中葉肥大を認める群の方が閉塞の程度は有 意差をもって強かった $(\mathrm{p}=0.0055$, カイ 2 乗検定).

なお weaak detrusor では $37.4 \%$ が, normal detrusor では $83.4 \%$ が IV 度以上の高度閉塞症例であった。

5 . 残尿量と最大尿流率

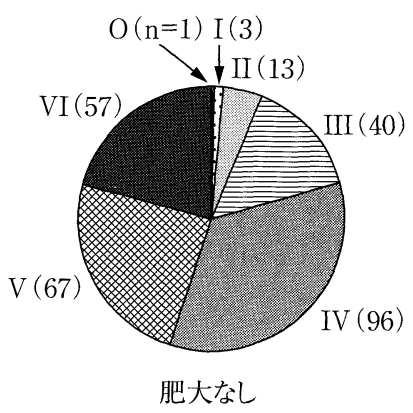

表 2 中葉肥大の有無と残尿量, 最大尿流率

\begin{tabular}{l|c|c}
\hline & 残尿量 $(\mathrm{ml})$ & 最大尿流率 $(\mathrm{ml} / \mathrm{m})$ \\
\hline 肥大あり & $128.0 \pm 102.2^{*}$ & $7.6 \pm 4.3^{\dagger}$ \\
肥大なし & $109.7 \pm 91.2^{*}$ & $8.7 \pm 4.2^{\dagger}$ \\
\hline & ${ }^{*} \mathrm{p}=0.04$ & ${ }^{\dagger} \mathrm{p}=0.007$ \\
\hline
\end{tabular}

平均值 $\pm \mathrm{SD}$

表 3 中葉肥大の有無と前立腺重量, 切除量

\begin{tabular}{l|c|c}
\hline & 前立腺重量 $(\mathrm{g})$ & 切除量 $(\mathrm{g})$ \\
\hline 肥大あり & $45.7 \pm 20.2^{*}$ & $26.6 \pm 19.3^{\dagger}$ \\
肥大なし & $41.7 \pm 18.1^{*}$ & $21.5 \pm 16.9^{\dagger}$ \\
\hline & ${ }^{*} \mathrm{p}=0.0081$ & ${ }^{\dagger} \mathrm{p}=0.0001$ \\
\hline
\end{tabular}

平均値 $\pm \mathrm{SD}$

閉塞の評価においてと同様，排尿筋収縮力が正常な 症例について残尿量と最大尿流率を検討した. 残尿量 は中葉肥大を認める群で $128.0 \pm 102.2 \mathrm{ml}$, 認めない群 で 109.7 $\pm 91.2 \mathrm{ml}$ と中葉肥大を認める群の方が有意差 をもって残尿量が多かった $(\mathrm{p}=0.04, \mathrm{t}$ 検定).また最大 尿流率は中葉肥大を認める群で $7.6 \pm 4.3 \mathrm{ml} / \mathrm{m}$, 認めな い群で $8.7 \pm 4.2 \mathrm{ml} / \mathrm{m}$ と中葉肥大を認める群の方が有 意差をもって低い結果となった $(\mathrm{p}=0.007, \mathrm{t}$ 検定) (表 2).

6. 前立腺重量, 切除量

前立腺重量は中葉肥大を認める群で $45.7 \pm 20.2 \mathrm{~g}$, 中 葉肥大を認めない群で $41.7 \pm 18.1 \mathrm{~g}$ と中葉肥大を認め る群の方が有意差をもって大きかった（ $\mathrm{p}=0.0081, \mathrm{t}$ 検定). また TUR-P 時の切除重量は中葉肥大を認める 群で $26.6 \pm 19.3 \mathrm{~g}$, 中葉肥大を認めない群で $21.5 \pm 16.9$ $\mathrm{g}$ と中葉肥大を認める群の方が有意差をもって大き かった（ $\mathrm{p}=0.0001$, t 検定）（表 3$)$. 


\section{考察}

前立腺肥大症の治療は，まず $\alpha$-blocker を中心とし た薬物療法を施行することが多いが，効果が不十分で ある場合は手術療法を考慮することとなる。手術療法 となるとやはり golden standard は TUR-P と思われ るが，そのような症例のなかでも中葉肥大の有無に よって閉塞症状の出方に違いがある印象をうける。 そ こで今回我々は手術前の PFS のデータと手術時の所 見を比較検討してみた。

一般的に前立腺肥大症は左右両葉の肥大結節が多い が，場合によっては中葉肥大を認める症例があり，最 近臨床の場で中葉肥大を認める症例が増加してきてい る印象がある.今回の検討では 1980 年代は中葉肥大を 認める割合は $10 \%$ 程度であったが, 少しずつ増加して きており最近では $30 \%$ 以上を占めている.海外の文献 での中葉肥大を認める割合については Randall'が報 告している $52 \%$ (中葉肥大のみが $30 \%$ ，三葉肥大が 22 \%）と比較すると当院の結果は少ないが, El Din"の $32.5 \%$ とは同程度である. 発生学的には中葉肥大は periurethral origin であり, transition zone の組織ではな い". transition zone は加齢とともに増大するが, 中葉 肥大は発生学的に違うため, 中葉肥大が増加している 理由としては加齢の問題だけではなく生活様式の欧米 化にあるかもしれないが，明らかではない．

また中葉肥大を認める症例は前立腺の大きさに関わ らず"，早くから閉塞症状が強く出やすい印象がある. そのため早くより医療機関を受診し，手術時の平均年 齢は中葉肥大を認める群の方が若いのではないかと予 測したが実際は差がなかった。

PFS を用いて排尿筋収縮力を評価したところ，中葉 肥大を認める群の方が収縮力は正常な症例が多かっ た．前立腺の肥大結節による閉塞がおきると，それに 反応して排尿筋収縮力が変化する．排尿笳収縮力が代 償可能な時期は圧を高めて尿流を保つことは可能であ るが，疲弊してくると様々な症状が出現してくると思 われる，中葉肥大を認める群の方が排尿筋収縮力は正 常な症例が多かったのは早くから閉塞症状が出やすい ため早期に病院を受診し，まだ排尿筋の疲弊が生じて いないためではないかと思われた。

閉塞に関しては, 閉塞 IV 度以上の強い閉塞は中葉 肥大を認める群の方が多い結果となった，症例が少な いためはっきりしたことは言えないが，中葉のみの肥 大結節でも半数以上の $53.1 \%$ が閉塞 IV 度以上の結果 となり, 中葉肥大のみでも閉塞症状は強く出るのでは
ないかと思われた，排尿時に中葉が valve 状になって 閉塞を起こすためにこのような結果となったのであろ j.

何をもって前立腺肥大症の手術的適応とするかにつ いては議論の分かれるところであると思われるが，当 院では，1）自覚症状を伴う，2）前立腺肥大結節が客 観的に認められる，3）排尿障害が客観的に認められ る5，以上の場合である.すなわち排尿障害が自他覚的 に認められ，それが前立腺肥大結節による閉塞といえ る症例である，1）はIPSSを，2）には超音波検查，尿 道造影検查，膀胱尿道鏡検查を，3）には尿流測定，残 尿測定を用いるのであるが，実際は排尿障害には，前 立腺肥大症だけではなく神経因性膀胱，前立腺肥大症 プラス神経因性膀胱の症例も混在しているため，前立 腺肥大症に伴う閉塞を客観的に証明することは意外と 難しいと思われる。これまでも前立腺重量と閉塞は相 関がある ${ }^{61}$ との報告や，IPSS と前立腺重量は相関が無 く, IPSS のみで BPH の予測は困難であるとの報告”が あり，単独の検査では情報量が十分とはいえない，そ のため最近はPFSを積極的に利用する施設も増えて いるが，検査が多少複雑で侵襲的であり機器も特殊な ため ${ }^{31}$ TUR-Pを施行するすべての施設でPFS が施行 可能であるという訳ではない.

客観的に high pressure low flow が証明されれば TUR-Pのよい適応であり ${ }^{8}$ ，PFS を利用すれば high pressure low flow を証明することは可能である。しか し同検査が梯々な理由で施行できない場合でも，今回 の結果をふまえると膀胱尿道鏡検査等にて，中葉肥大 が証明されれば high pressure low flow である可能性 が高いのではないかと推測される，また実際に，膀胱 尿道鏡とウロダイナミックスとの結果は相関するとの 報告”もある。つまり中葉肥大を認める症例では，手術 的方法を視野に入れて治療をすすめていってもよいの ではないかと思われた。

\section{文献}

1) Schäfer, W. : Basic principles and clinical application of advanced analysis of voiding bladder function. Urol. Clin. North. Am.. 17. 553-566. 1990.

2) Randall, A.: Surgical pathology of prostatic obstrution. Williams \& Wilkins, Baltimore., 1931.

3）後藤百万：ウロダイナミックスにおけるプレ シャーフロースタディの位置. 排尿障害プラク ティス, 5,224-231.1997.

4) El Din, K.E., de Wildt, M.J., Rosier. P.F., Wijkstra, H.. Debruyne, F.M. and de la Rossete, J.J. : The 
correlation between urodynamic and cystoscopic findings in elderly men with voiding complaints. J. Urol., 155, 1018-1022, 1996.

5）伊藤泰：：前立腺肥大症に対する TUR-P の要点. p16-19, メディカルビュー社, 東宗, 1993.

6) Rosier, P.F. and de la Rosette, J.J. : Is there a correlation between prostate size and bladder-outlet obstrution. World J. Urol., 13, 9-13, 1995.

7) Bosch, J.L.. Hop, W.C., Kirkeles, W.J. and Schroder, F.H. : The International Prostate Symptom Score in a community-based sample of men between 55 and 74 years of age : prevalence and correlation of symptoms with age, prostate volume, flow rate and residual urine volume. Br. J. Urol., 75, 622-630, 1995.

8）武井実根雄：前立腺肥大症 (2) 一 TUR-P の適忍へ の選択-Low-pressure low flow の扱い. 排沊障害 プラクティス， 5,237-243, 1997.

9) John, D. McConnell : Epidemiology, etiology, pathophysiology, and diagnosis of benign prostatic hyperplasia. In Campbell's Urology, 7 th ed., p 1437-1438, Saunders Co., Philadelphia, 1997.

(2001 年 1 月 5 日受付, 8 月 29 日受理) 